Altai State University

www.asu.ru

ISSN 2412-1908

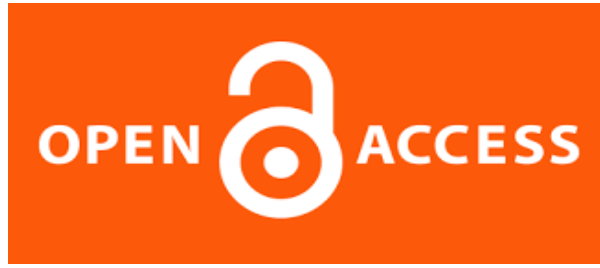

Acta Biologica Sibirica, 2018, 4(1), 38-45

UDK 595.798

\title{
On the expansion of the areas of Vespa orientalis and Polistes wattii (Hymenoptera: Vespidae) on the territory of the Republic of Kazakhstan
}

\author{
I.I. Temreshev \\ LLP "Kazakh SRI of Plant Protection and Quarantine named Zh. Zhiembayev" Ministry of Agriculture of Republic of \\ Kazakhstan, 050070, Almaty, Nauryzbaysky district, md. Rahat, Kultobe street, 1, Kazakhstan \\ temreshev76@mail.ru
}

\begin{abstract}
The new data received on the distribution of two species of social wasps in the territory of the Republic of Kazakhstan-the eastern, or Vespa orientalis Linnaeus, 1771 (Oriental hornet), and the Polistes wattii Cameron, 1900. Currently in territory of Almaty oblast there is a stable self-reproducing population of the $V$. orientalis and its range is constantly expanding. On the territory of the Zhambyl oblast, it was previously recorded in the Talas district, but for Shu and Sarysu districts not indicated. In the Kyzylorda oblast, it was previously recorded in the Syrdarya district, for the Zhanakorgan district not specified. In general, it not specified earlier for the Karaganda oblast. Thus, in general, the territory of Kazakhstan is expanding its range. P. wattii in Kazakhstan was observed relatively recently (2012, the villages of Shardara and Asykata in Shardara and Maktaaral districts of the South Kazakhstan oblast). North of the indicated points of South Kazakhstan and in the Kyzylorda and Zhambyl oblasts, it was not previously indicated. Apparently, the species gradually expands its area within the Republic of Kazakhstan. Both species are of practical importance as pests of agriculture and beekeeping, and sanitary and epidemiological and medical - as poisonous animals. In addition, their introduction into new habitats can disrupt the existing ecological balance. Proceeding from, is necessary to monitor further spreading of these wasps within Kazakhstan, and to start working on the issue of measures to limit their numbers taking into account world experience. Key words: Social wasps, Hymenoptera, Vespidae, Vespinae, Polistinae, Vespa orientalis, Polistes wattii, Kazakhstan.
\end{abstract}

\section{О расширении ареалов Vespa orientalis и Polistes wattii (Hymenoptera: Vespidae) на территории Республики Казахстан}

\section{И.И. Темрешев}

ТОО «Казахский Научно-исследовательский институт защиты и карантина растений им. Ж. Жиембаева» Министерства сельского хозяйства Республики Казахстан 050070, г. Алматы, Наурызбайский район, мкр. Рахат, ул. Култобе, 1, Республика Казахстан temreshev76@mail.ru

\footnotetext{
Получены новые данные о распространении двух видов общественных складчатокрылых ос на территории Республики Казахстан - Vespa orientalis Linnaeus, 1771 (восточного, или туркестанского шершня), и Polistes wattii Cameron, 1900 (полиста Ватти). В настоящее время на территории Алматинской области имеется устойчивая самовоспроизводящаяся популяция $V$. orientalis, и его ареал постоянно расширяется. На территории Жамбылской
} 
Temreshev, I.I. On the expansion of the areas of Vespa orientalis and.... Acta Biologica Sibirica, 2018, 4(1), 38-45

области он ранее отмечался в Таласском районе, но для Шуского и Сарысуйского районов указан не был. В Кызылординской области ранее отмечался в Сырдариинском районе, для Жанакорганского района не указывался. Вообще не указывался ранее для Карагандинской области. Таким образом, в целом на территории Казахстана происходит расширение его ареала. Р. wattii в Казахстане был отмечен относительно недавно (2012 г., поселки Шардара и Асыката в Шардаринском и Мактааральском районах Южно-Казахстанской области). Севернее указанных точек Южно-Казахстанской и в пределах Кызылординской и Жамбылской областей он ранее не указывался. По всей видимости, вид постепенно расширяет свой ареал в пределах Республики Казахстан. Оба вида имеют практическое значение в качестве вредителей сельского хозяйства и пчеловодства, и санитарноэпидемиологическое и медицинское - в качестве ядовитых животных. Кроме того, их вселение в новые биоценозы может нарушить существующее экологическое равновесие. Исходя из этого, необходимо проводить мониторинг дальнейшего расселения этих видов ос в пределах Казахстана, и начать проработку вопроса о мероприятиях по ограничению их численности с учетом мирового опыта.

Ключевые слова: общественные осы, Hymenoptera, Vespidae, Vespinae, Polistinae, Vespa orientalis, Polistes wattii, ареал, Казахстан

\section{Введение}

Общественные складчатокрылые осы относятся к семейству Настоящих ос (Vespidae). Оно включает 5274 видов, 256 родов, 6 подсемейств (Antropov, Fateryga, 2017). Ранее подразделялось на 3 самостоятельных семейства: общественных, или «бумажных» ос, Vespidae, цветочных ос Masaridae и одиночных складчатокрылых oc Eumenidae. В настоящее время всех складчатокрылых ос объединяют в единое семейство Vеspidae с подсемействами Euparagiinae, Masarinae, Eumeninae, Stenogastrinae, Vespinae и Polistinae. В покое передние крылья складываются вдоль спины. Окраска яркая, разнообразная, на брюшке рисунок часто состоит из чередующихся чёрных и жёлтых полос (Кудель, 1974; Тобиас, 1978; Курзенко, 1995; Антропов, Хрусталева, 2009a, b; Spradbery, 1973; Ebeling, 2002; Robinson, 2005; Antropov, Fateryga, 2017). Есть как одиночно живущие виды, так и формы, ведущие общественный образ жизни (имеющие плодовитых и бесплодных самок - рабочих) и строящие сложные гнёзда из «бумаги» - измельченной и обработанной слюной древесной массы, каста рабочих отличается от маток размерами и недоразвитыми половыми железами (общественные, или бумажные осы). Одиночные осы хищники, питаются и выкармливают личинок насекомыми, Masarinae - пыльцой. Общественные осы питаются нектаром, падью тлей, древесным и фруктовым соком, другими сахаросодержащими веществами, выделениями личинок. Личинок они выкармливают разжеванной рабочими особями животной и частично растительной пищей, некоторые тропические виды кормят их даже мелкими грызунами, ящерицами и птицами, иногда кормят падалью и пищевыми отходами (Кудель, 1974; Тобиас, 1978; Кипятков, 1991; Курзенко, 1995; Казенас, Николаев, 2004; Антропов, Хрусталева, 2009a, b; Spradbery, 1973; Ebeling, 2002; Robinson, 2005; Antropov, Fateryga, 2017). Положительное экономическое значение общественных ос обусловлено истреблением ими большого числа вредных насекомых во время выкармливания личинок. Отрицательное значение - повреждение фруктов, мясной продукции, коры деревьев при сборе древесной массы для постройки гнезда, уничтожение большого числа медоносных пчел, ядовитые ужаления, иногда с тяжелыми последствиями, особенно для детей и взрослых, обладающих повышенной чувствительностью к ядам насекомых. Гнезда часто служат местами резервации амбарных вредителей, таких как кожееды, притворяшки, моли и другие. Некоторые виды общественных складчатокрылых ос (Vespula vulgaris (Linnaeus, 1758) (оса обыкновенная), V. germanica (Fabricius, 1793) (оса германская), V. rufa (Linnaeus, 1758) (оса рыжая), V. pensylvanica Saussure, 1857 (оса пенсильванская), Vespa сrabro Linnaeus, 1758 (шершень обыкновенный), V. orientalis (шершень восточный, или туркестанский), V. velutina Lepeletier, 1836 (шершень азиатский), Polistes gallicus (Linnaeus, 1767) (оса французская), P. dominula (Christ, 1791) (оса европейская) и др.), были случайно интродуцированы в несвойственные им места обитания - Северную и Южную Америку, Австралию, Новую Зеландию, на Гавайские о-ва, Европу, Южную Африку, и т.п. Там они сильно размножились и превратились в серьезных вредителей, наносящих значительный экономический ущерб. Кроме того, они агрессивны по отношению к местным видам насекомых и конкурируют с птицами и другими животными за пищевые ресурсы. Так, потребляя большое количество нектара цветов, они не только лишают пищи коренных насекомых и птиц, но и нарушают естественные процессы опыления растений. Ужаления, наносимые ими людям и домашним животным, также являются серьезной проблемой. Oca V. vulgaris была внесена в Список 100 самых опасных инвазивных видов, оказавших наибольшее негативное влияние на деятельность человека и аборигенные виды, составленный группой специалистов МСОП (Попов, 1948, 1949; Кудель, 1974; Тобиас, 1978; Песенко, 1981; Орлов, Гелашвили, Ибрагимов, 1990; Кипятков, 1991; Курзенко, 1995; Казенас, Николаев, 2004; Ромашкова, Дашев, 2005; Бородина, 2009; Антропов, Хрусталева, 2003; Альтманн, 2004; Алешо, 2008; Антропов, Хрусталева, 2009a, b; Милько, 2009; Темрешев, и др., 2015; Темрешев, 2017; Spradbery, 1973; Ebeling, 2002; Potter, Beavers, 2005; Robinson, 2005; Goddard, 2007; Roques et al, 2010).

Таким образом, изучение распространения отдельных видов общественных складчатокрылых ос на территории Казахстана является актуальным как в научном, так и в практическом и медицинском плане. 
Temreshev, I.I. On the expansion of the areas of Vespa orientalis and.... Acta Biologica Sibirica, 2018, 4(1), 38-45

\section{Материал и методы исследований}

Основой для данной работы послужили сборы автора, сделанные в 2015-2017 гг. на юге и юго-востоке Казахстана. Кроме того, были просмотрены сборы коллег. Алматинская, Жамбылская, Южно-Казахстанская, Кызылординская и Карагандинская области, далее сокращены как АО, жО, ЮКО, КО и КАО. Также сокращены фамилии сборщиков: ИТ - И.И. Темрешев, ПЕ - П.А. Есенбекова, ВЛК - В.Л. Казенас, НП - Н.В. Постоева, и административные единицы: р-н - район, г. - город, п. - поселок, вдхр. - водохранилище, оз. - озеро, окр. окрестности. При сборе материала применялись отлов энтомологическим сачком, осмотр древесно-кустарниковых и травянистых растений, жилых и хозяйственных строений, ручной сбор пинцетом и в морилку, визуальный учет, фотографирование. Для идентификации видов и определения информации об их биоэкологических особенностях, распространении и естественных регуляторах численности использовались источники из списка литературы. Материал частично хранится в коллекции автора, за исключением большого количества экземпляров, использованных для проведения лабораторных анализов на содержание поллютантов (пестицидов и тяжелых металлов), либо небольшой части, переданной на хранение в коллекцию Биологического музея Казахского Национального Университета имени Аль-Фараби. Координаты и даты мест сбора материала, список обследованных биотопов, обозначенные номерами, представлены в таблице 1.

таблица 1. Места сбора материала по Vespa orientalis и Polistes wattii в Казахстане

\begin{tabular}{|c|c|c|}
\hline № & Место и дата сбора & Координаты \\
\hline 1 & ЮКО, Мактааральский р-н, окр. п. Асыката, 14.08.2013 & N 4053'42.68"; E 68²0'24.31" \\
\hline 2 & $\begin{array}{l}\text { ЮКО, г. Шардара, частный дом с садом на берегу р. Сырдарья, } \\
\text { 10.06.2015 }\end{array}$ & N 4116'22.3"; E 6757'08.8" \\
\hline 3 & ЮКО, Шардаринский р-н, берег вдхр. Шардара, 10.06.2015 & N 41ํ14'48.4"; E 67o58'26.7" \\
\hline 4 & ЮКО, Шардаринский р-н, 15 км С-3 вдхр. Шардара, 11.06.2015 & N 41ํ12'47.8"; E 68¹1'52.4" \\
\hline 5 & $\begin{array}{l}\text { ЮКО, Шардаринский р-н, } 14 \text { км С-3 вдхр. Шардара, арбузная бахча, } \\
\text { 11.06.2015 }\end{array}$ & N 41ำ1'02.3"; E 68¹0'21.0" \\
\hline 6 & ЮКО, Мактааральский р-н, окр. п. Асыката, хлопковое поле, 13.06.2015 & N 405'29.9"; E 68²2'42.1" \\
\hline 7 & $\begin{array}{l}\text { ЮкО, Мактааральский р-н, окр. п. Асыката, пустырь с тамариском, } \\
\text { 13.06.2015 }\end{array}$ & N 405'ㄴ'29.9"; E 68²2'42.1" \\
\hline 8 & ЮкО, Мактааральский р-н, окр. п. Атакент, кукурузное поле, 13.06.2015 & N 4052'45.4"; E 68²9'20.7" \\
\hline 9 & $\begin{array}{l}\text { ЮКО, Шардаринский р-н, окр. п. Коксеит, берег Кызылкумского канала, } \\
\text { 14.06.20015 }\end{array}$ & N 41ํ23'26.1"; E 67º57'55.4" \\
\hline 10 & $\begin{array}{l}\text { ЮКО, Шардаринский р-н, окр. п. Коксу, берег Кызылкумского канала, } \\
\text { 14.06.2015 }\end{array}$ & N 41 ${ }^{\circ} 28^{\prime} 17.7^{\prime \prime} ;$ E 67º57'37.2" \\
\hline 11 & $\begin{array}{l}\text { ЮКО, Шардаринский р-н, окр. п. Суткент, берег Кызылкумского канала, } \\
\text { 14.06.2015 }\end{array}$ & 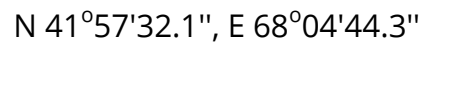 \\
\hline 12 & ЮКО, Ордабасинский р-н, окр. вдхр. Боген, 15.06.2015 & N 424'27.7"; E 6900'25.2" \\
\hline 13 & ЮКО, Толебийский р-н, окр. п. Маятас, берег вдхр. Бадам, 16.06.2015 & N 4213'29.5"; E 6946'47.9" \\
\hline 14 & АО, Алакольский р-н, берег озера Алаколь, зона отдыха, 5.08.2015 & N 4549'19.64"; E 8148'36.90" \\
\hline 15 & жО, Шуский р-н, окр. вдхр. Тасоткель, 4.06.2016 & N 4322'73.0"; E 7356'42.2" \\
\hline 16 & ЖО, Шуский р-н, пшеничное поле 544 м к С от вдхр. Тасоткель, 5.06.2016 & N 4323'5.55"; E 7356'38.49" \\
\hline 17 & ЖО, Шуский р-н, пастбище на берегу вдхр. Тасоткель, 5.06.2016 & N 4323'1.52"; E 7356'52.75" \\
\hline 18 & $\begin{array}{l}\text { ЖО, Шуский р-н, пшеничное поле } 8,95 \text { км к С-3 от вдхр. Тасоткель, } \\
\text { 5.06.2016 }\end{array}$ & N 4326.30"; E 7353.17" \\
\hline 19 & ЖО, Шуский р-н, лугостепь 17,2 км к 3 от п. Бельбасар, 5.06.2016 & N 4329'19.01"; E 7349'24.25" \\
\hline 20 & ЖО, Таласский р-н, г. Каратау, частный дом, 7.06.2016 & N 4111'410"; E 70²7'47.1" \\
\hline 21 & жО, Таласский р-н, берег оз. Биликоль, 6.06.2016 & N 4306'008"; E 7041'328" \\
\hline 22 & жО, Таласский р-н, окр. п. Концовка, степь, 7.06.2016 & N 4305'498"; E 7040'525" \\
\hline 23 & жО, Таласский р-н, оз. Жартас, 7.06.2016 & N 4311'54.0"; E 70²8'34.5" \\
\hline 24 & АО, Талгарский р-н, УНПЦ «БайсеркеАгро», люцерник, 19.06.2016 & N 4329'26.54"; E 77 1'24.02" \\
\hline 25 & АО, окр. г. Капшагай, 30.06.2016 & N 4354'24.73"; E 77 5'6.57" \\
\hline 26 & ЖО, Шуский р-н, п. Беткайнар, 18.04.2017 & N 4312'38"; E 74²7'50" \\
\hline 27 & ЮКО, Отырарский р-н, п. Шаульдер, 26.04.2017 & N 4247'15.37"; E 68²2'32.58" \\
\hline 28 & $\begin{array}{l}\text { КО, Жанакорганский р-н, окр. п. Жанакорган, берег оз. Колдыколь, } \\
\text { 23.05.2017 }\end{array}$ & N 435'083"; E 67¹2'983" \\
\hline 29 & КО, Жанакорганский р-н, окр. п. Шалкия, полупустыня, 24.05.2017 & N 4359'471"; E 67²4'577" \\
\hline 30 & $\begin{array}{l}\text { ЮКО, Туркестанский р-н, участок степи по дороге на г. Туркестан, } \\
\text { 24.05.2017 }\end{array}$ & N 4326'192"; E 6758'518" \\
\hline 31 & ЮкО, Туркестанский р-н, окр. г. Туркестан, 24.05.2017 & N 4319'24.50"; E 68¹2'42.38" \\
\hline
\end{tabular}


Temreshev, I.I. On the expansion of the areas of Vespa orientalis and.... Acta Biologica Sibirica, 2018, 4(1), 38-45

\begin{tabular}{|c|c|c|}
\hline 32 & $\begin{array}{l}\text { ЮКО, Кентауский р-н, г. Кентау, пустырь в зоне комбината } \\
\text { «Полиметалл», 25.05.2017 }\end{array}$ & N 43․31'640"; E 68²9'680" \\
\hline 33 & ЮКО, Кентауский р-н, окр. вдхр. Кентау, 25.05.2017 & N 4327'837"; E 68²9'330" \\
\hline 34 & ЮКО, Кентауский р-н, сад на выезде из г. Кентау, 25.05.2017 & N 4329'592"; E 68²9'526" \\
\hline 35 & ЖО, Сарысуйский р-н, берег оз. Ынталы, 29.05.2017 & N 4340'408"; E 6957'030" \\
\hline 36 & жО, Таласский р-н, берег оз. Акколь, 30-31.05.2017 & N 4324'282"; E 7045'526" \\
\hline 37 & АО, г. Алматы, территория КНЦКЗИ им. М. Айкимбаева, 5.09.2017 & N 4320'19.96"; E 7658'38.21" \\
\hline 38 & КАО, Улытауский район, п. Богдок, 19.10.2017 & N 4652'0.05"; E 64²40'0.31" \\
\hline 39 & КО, Жанакорганский р-н, окр. п. Жанакорган, 21.10.2017 & N 4355'8.25"; E 67¹4'14.61" \\
\hline 40 & КО, Жанакорганский р-н, окр. п. Байкенже, 21.10.2017 & N 435'32.41"; E 6655'19.32" \\
\hline
\end{tabular}

\section{Результаты и обсуждение}

В ходе проведенных исследований были получены новые данные о распространении двух видов общественных складчатокрылых ос на территории Республики Казахстан. Характеристики видов с данными об их биологии, хозяйственном значении и распространении, а также новая информация приводятся ниже:

Vespa orientalis (Рис. 1, 2). Длина тела рабочих ос 22-26, самцов 23-31, самок 29-32 мм. Голова красноватокоричневая, наличник желтый. Грудь коричневая. Большая часть брюшка также коричневого цвета, за исключением 3-4-го сегментов, частично окрашенных в желтый цвет. На желтом фоне каждого из этих сегментов имеются по 2 коричневых пятнышка. Усики и ноги красновато-коричневые, голени и лапки светлее, с желтоватым оттенком. Группой израильских и британских учёных было выяснено, что пигмент ксантоптерин в светлой полосе брюшка насекомых поглощает солнечный свет и преобразует его в электричество. Видимо, по этой причине эти шершни более активны в солнечные дни (Plotkin et al., 2010). Гнезда строит в дуплах деревьев, щелях на каменистых склонах, в заборах и стенах зданий, под крышами. Для личинок ловит разнообразных насекомых жуков, прямокрылых, двукрылых, стрекоз, различных перепончатокрылых, в частности, медоносных пчел и общественных ос из рода Vespula и Polistes, а также пауков. Повреждает зрелые плоды винограда, абрикоса, персика, сливы, цитрусовых и других фруктовых на деревьях и во время переработки. Обгладывает кору молодых плодовых деревьев и саженцев. Кроме того, вредит лесному хозяйству, пчеловодству, убивая в большом количестве (до 33 за 1 час) медоносных пчел для выкармливания потомства, пищевым запасам (фрукты, кондитерские изделия, мясо и мясная продукция). Зарегистрировано большое число случаев ужаления человека и домашних животных с тяжелыми последствиями. В Средней Азии и на юге Казахстана часто селится в толще стен глинобитных домов с летными отверстиями с наружной стороны стены. В домах, на рынках и пунктах общественного питания ведет себя подобно комнатной мухе, повреждая сахар, конфеты, варенье, сушеные фрукты, вяленые дыни, мясную продукцию. Может механически переносить возбудителей инфекционных болезней, поскольку охотно садится на различные отбросы и экскременты (Попов, 1948, 1949; Песенко, 1981; Казенас, Николаев, 2004; Антропов, Хрусталева, 2009а; Милько, 2009; Ильина, Гасанова, 2012; Темрешев, 2017; Spradbery, 1973; Al-Ghamdi, 1990; Archer, 1998; Klein, Zarabi, 2003; Al-Ghamdi, 2004; Robinson, 2005; Bacandritsos et al, 2006; Ghahari et al, 2007; Goddard, 2007; Glaiim, 2009; Abdelaal, El-defrawy, 2014). Естественные регуляторы численности: обыкновенный богомол Mantis religiosa (Linnaeus, 1758), наездник Sphecophaga vesparum Curtis, 1828, золотистая щурка Merops apiaster Linnaeus, 1758 (Мейер, 1936; Атанасов, Йонайтис, Каспарян, 1981; Bacandritsos et al, 2006). Распространение: Европа, Северная Африка, Аравийский п-ов, о. Крит, о. Кипр, Малая Азия, Ближний Восток, Кавказ, Закавказье, юг Европейской части Росии, Южный и Юго-Восточный Казахстан, Кыргызстан, Туркменистан, Таджикистан, Узбекистан, Китай, Иран, Ирак, Афганистан, Пакистан, Индия, Непал, Эфиопия. Завезен в США, Мексику, некоторые страны Европы, Северную Африку, Юго-Восточную Азию, на о. Мадагаскар (Давлетшина, Аванесова, Мансуров, 1979; Милько, 2009; Ильина, Гасанова, 2012; Казенас, 2014; Темрешев и др., 2015; Темрешев, 2017; Carpenter, Kojima, 1997; Archer, 1998; Ebeling, 2002; Robinson, 2005; Castro, Dvorak, 2010; Roques et al, 2010; Ebrahimi, Carpenter, 2012; Antropov, Fateryga, 2017).

материал: 1 - 1 , ПЕ; 2 - 5 ㅇ, ВЛК, ИТ; 3 - 7 ㅇ, ВЛК, ИТ; 4 - 2 ㅇ, ВЛК; 5 - 3 , ВЛК; 6 - 2 ㅇ, ВЛК; 7 - 2 ㅇ, ВЛК; 8 - 2 ㅇ,

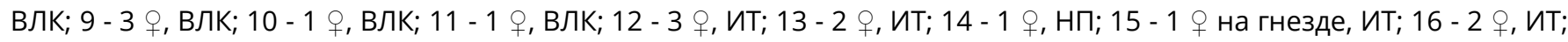

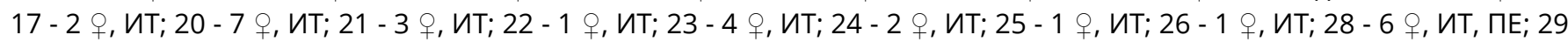

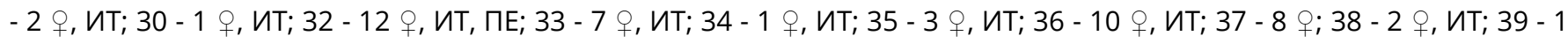
ㅇ, ИТ; $40-2$ ㅇ $и \mathrm{UT}$.

В Кадастре животного мира Алматинской области V. orientalis не указывается (Мелдебеков, Казенас, Жатканбаева и др., 2011; Мелдебеков, Казенас, Байжанов и др., 2011). В Алматинской области он относительно недавно (2015 г.) был найден в Алакольском р-не Н.В. Постоевой (N 4549'19.64"; Е 8148'36.90"). По устному сообщению В.Г. Мека-Меченко, большое количество особей данного вида было отмечено в 1997 г. окрестностях п. Казахстан Енбекшиказахского р-на Алматинской области (N 43³2'17.53"; E 77²5'57.02"). Осы прилетели на запах крови, выделявшейся при вскрытии и обработке тушки большой песчанки Rhombomys opimus (Lichtenstein, 1823), и вели себя настолько агрессивно, что практически не дали возможности провести зоопаразитологическое обследование грызуна. Кроме того, им же было сообщено, что колония V. orientalis существовала в г. Алматы на территории Казахского научного центра карантинных и зоонозных инфекций им. М. Айкимбаева МЗ РК в 2007 г. В 
Temreshev, I.I. On the expansion of the areas of Vespa orientalis and.... Acta Biologica Sibirica, 2018, 4(1), 38-45

августе-сентябре 2017 г. там же автором наблюдалась утренняя охота нескольких особей V. orientalis. Объектом охоты служили разные виды саранчовых (Acrididae) - итальянский прус Calliptamus italicus (Linnaeus, 1758), пустынный прус C. barbarus (Costa, 1836), голубокрылая кобылка Oedipoda caerulescens (Linnaeus, 1758), бурый конек Chorthippus apricarius Linnaeus, 1758 и краснобрюхая травянка Omocestus haemorrhoidalis (Charpentier, 1825), гревшиеся на асфальтовых дорожках после ночного снижения температуры. Кроме саранчовых, шершни охотились на настоящих кузнечиков (Tettigoniidae) - пятнистого Platycleis intermedia (Audinet-Serville, 1838) и зеленого Tettigonia viridissima (Linnaeus, 1758), а также поедали падалицу плодовых деревьев - абрикоса, яблони и др.

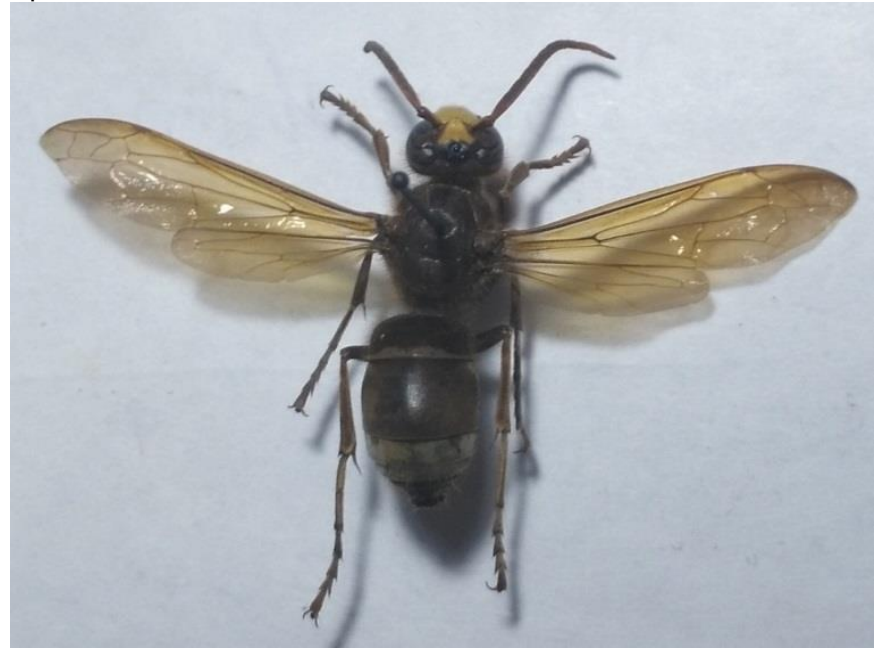

Рис. 1. Восточный, или туркестанский шершень Vespa orientalis (фото И.И. Темрешева из личной коллекции)

Polistes wattii (Рис. 3). Длина тела самки 11-12 мм, самца 10-11 мм. По окраске резко отличается от других казахстанских видов полистов. Тело почти равномерно желтое; некоторые экземпляры коричневые с желтой среднегрудью, иногда на усиках имеется черное пятно на вершине, узкая черная полоска вокруг каждого глазка. Задние голени выше, как правило, черные. На 1-м тергите брюшка узкая поперечная красноватокоричневая линия, на 2-5 тергитах и стернитах имеется изогнутая красновато-коричневая линия; у некоторых экземпляров 2 изогнутых коричневых линии на переднегруди. Гнездо как у других видов полистов, открытое, в виде единственного сота, светло-серого цвета, насчитывает несколько десятков ячеек, реже больше сотни. Гнездится в дуплах, на ветках деревьев и крупных травянистых растениях, в щелях и выемках заборов, гаражей, стен зданий, на чердаках и балконах. частности, гусеницами чешуекрылых и ложногусеницами пилильщиков, чем приносит пользу. Имаго посещают цветы, как и другие виды полистов. Вредная деятельность: повреждает спелые фрукты на деревьях, во время сушки и переработки, и их запасы, а также различные пищевые продукты. Может нападать на ослабленные ульи медоносной пчелы, убивать пчел для выкармливания личинок, и воровать мед. Также, как и другие общественные осы, может собирать корм личинкам на падали и отбросах (Al-Ghamdi, 1990, 2004; Kumar, Sharma, 2014; Gess, Roosenchoon, 2016). Имеются сообщения, что после его появления в г. Ташкенте другие виды полистов начали исчезать (форум http://antclub.org/node/6083). Естественный регулятор численности: муха-ктырь Saropogon pollinosus Loew, 1869 (Ghahari et al., 2007). Распространение: Аравийский п-ов, о. Маврикий, Ирак, Иран, Казахстан (юг), Туркменистан, Таджикистан, Узбекистан, Афганистан, Пакистан, Индия, Китай (Казенас, 2014; Мокроусов, Зрянин, 2015; Темрешев и др., 2015; Темрешев, 2017; Carpenter, 1996; Kumar, Sharma, 2014; Gess, Roosenchoon, 2016).

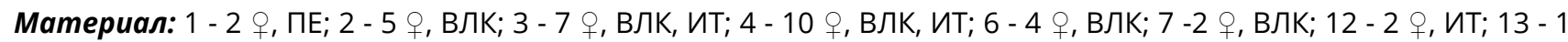

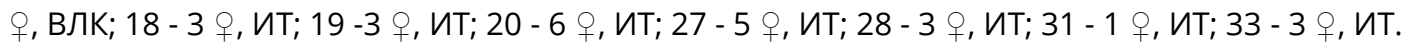

\section{Обсуждение}

В настоящее время можно говорить о том, что на территории Алматинской области имеется устойчивая самовоспроизводящаяся популяция V. orientalis, и его ареал постоянно расширяется. На территории Жамбылской 
Temreshev, I.I. On the expansion of the areas of Vespa orientalis and.... Acta Biologica Sibirica, 2018, 4(1), 38-45

области он ранее отмечался в Таласском р-не (Казенас, 2014), но для Шуского и Сарысуйского р-нов указан не был. В Кызылординской области ранее отмечался в Сырдариинском р-не (Казенас, 2014), для Жанакорганского р-на не указывался. Вообще не указывался ранее для Карагандинской области.

P. wattii в Казахстане был отмечен относительно недавно (2012 год, пп. Шардара и Асыката в Шардаринском и Мактааральском р-нах Южно-Казахстанской области) (Казенас, 2014). Севернее указанных точек ЮжноКазахстанской и в пределах Кызылординской и Жамбылской областей он ранее не указывался. По всей видимости, вид постепенно расширяет свой ареал в пределах Республики Казахстан.

В результате проведенных исследований было установлено расширение ареалов двух видов общественных складчатокрылых ос на территории Республики Казахстан - V. orientalis, и P. wattii. Оба вида имеют практическое значение в качестве вредителей сельского хозяйства и пчеловодства, и санитарно-эпидемиологическое и медицинское - в качестве ядовитых животных. Кроме того, их вселение в новые биоценозы может нарушить существующее экологическое равновесие. Исходя из вышеизложенного, необходимо проводить мониторинг дальнейшего расселения этих видов ос в пределах Казахстана, и начать разработку мероприятий по ограничению их численности с учетом мирового опыта в данном вопросе.

\section{Благодарности}

Работа подготовлена в рамках выполнения работ по бюджетной программе 217 «Развитие науки» подпрограмме 101 «Программно-целевое финансирование субъектов научной и/или научно-технической деятельности» по приоритету «Наука о жизни», по НТП 0206/ПЦФ «Инновационное научно-техническое обеспечение фитосанитарной безопасности в Республике Казахстан» и ГФ 4163 «Мониторинг экологического состояния наземных и водных экосистем Южного Казахстана с использованием индикаторных видов беспозвоночных» Министерства образования и науки Республики Казахстан.

Автор выражает благодарность В.Г. Мека-Меченко (Казахский научный центр карантинных и зоонозных инфекций им. М. Айкимбаева МЗ РК, Алматы, Казахстан), П.А. Есенбековой и В.Л. Казенасу (РГП Институт зоологии KH МOH РК, Алматы, Казахстан), Н.В. Постоевой (TOO «AGS Pro Engineering», Алматы, Казахстан) и Д.А. Милько (Биолого-почвенный институт НАН КР, Бишкек, Кыргызстан) за предоставленные информацию, материалы и присланные копии статей, а также за предоставленные ими фотографии ос В.Л. Казенасу и Н.Ж. Турубаеву (Алматы, Казахстан).

\section{References}

Abdelaal A.A.A., El-defrawy B.M. (2014). Efficacy of new designed traps for controlling the Oriental hornet (Vespa orientalis) in egyptian apiaries and its measurements. International Journal of Advanced Research, 2, 10, 1-8.

Alesho N.A. (2008). Sluchai negativnogo kontakta cheloveka s predstaviteljami nekotoryh vidov os semejstva Vespidae. Pest Management, 2, 54-55 (In Russian).

Al-Ghamdi A.A. (1990). Survey of honeybee diseases, pests and predators in Saudi Arabia. University of Wales, Cardiff.

Al-Ghamdi A.A. (2004). Diseases and pests associated with honeybee colonies in Saudi Arabia. Minia J. of Agric. Res. Develop, 24, 2, 191-210.

Al'tmann H. (2004). Jadovitye rastenija i zhivotnye. Spravochnik. M.: BMM AO (In Russian).

Antropov A.V., Fateryga A.V. (2017). Superfamily Vespoidea. 68. Family Vespidae. In Book: Antropov A.V., Astafurova Yu.V., Belokobylskij S.A., Byvaltsev A.M., et al. Annotated catalogue of the Hymenoptera of Russia. Volume I. Symphyta and Apocrita: Aculeata. Proceedings of the Zoological Institute RAS. Supplement 6. SPb.

Antropov A.V., Hrustaleva N.A. (2003). Obshhestvennye osy. Pest Killer, 1, 1-4 (In Russian).

Antropov A.V., Hrustaleva N.A. (2009a). Vidovoj sostav, osobennosti biologii i rasprostranenie v Rossii obshhestvennyh os (Insecta: Hymenoptera: Vespidae), predstavljajushhih potencial'nuju opasnost'. Chast' 1. Podsemejstvo Polistinae (Rod Polisty - Polistes Latreille, 1802), podsemejstvo Vespinae (Rod Shershni - Vespa Linnaeus, 1758). Pest Management, 1, 54 (In Russian).

Antropov A.V., Hrustaleva N.A. (2009b). Vidovoj sostav, osobennosti biologii i rasprostranenie v Rossii obshhestvennyh os (Insecta: Hymenoptera: Vespidae), predstavljajushhih potencial'nuju opasnost'. Chast' 2. Podsemejstvo Vespinae (Rod Korotkoshhekie osy - Vespula Thomson, 1869; rod Dlinnoshhekie osy - Dolichovespula Rohwer, 1916). Pest Management, 3, 34-39. (In Russian).

Archer M.E. (1998). Taxonomy, distribution and nesting biology of Vespa orientalis L. (Hym., Vespidae). Entomologist's Monthly Magazine, 138, 45-51.

Atanasov A.Z., Jonajtis V.P., Kasparjan R.D. i dr. (1981). Semejstvo Ichneumonidae - Ihnevmonidy. In book: Opredelitel' nasekomyh evropejskoj chasti SSSR. T. III. Pereponchatokrylye. Ch. 6. L.: Nauka (In Russian).

Bacandritsos N., Papanastasiou I., Saitanis C., Roinioti E. (2006). Three non-toxic insect traps useful in trapping wasps enemies of honey bees. Bulletin of Insectology, 59 (2), 135-145.

Borodina L.N. (2000). Osy na paseke. Pchelovodstvo, 7, 12. (In Russian).

Carpenter J.M. (1996). Distribution checklist of species of the genus Polistes (Hymenoptera: Vespidae: Polistinae: Polistini). American Museum Novitates, 3188, 1-36. 
Temreshev, I.I. On the expansion of the areas of Vespa orientalis and.... Acta Biologica Sibirica, 2018, 4(1), 38-45

Carpenter J.M., Kojima J. (1997). Checklist of the species in the subfamily Vespinae (Insecta: Hymenoptera: Vespidae). Natural History Bulletin of Ibaraki University, 1, 51-92.

Castro L., Dvorak L. (2010). New and noteworthy records of vespid wasps (Hymenoptera: Vespidae) from the Palaearctic region (III). Acta Musei Moraviae, Scientiae biologicae, 95 (2), 37-53.

Davletshina A.G., Avanesova G.A., Mansurov A.K. (1979). Jentomofauna jugo-zapadnogo Kyzylkuma. Tashkent: Izd-vo «Fan» Uzbekskoj SSR (In Russian). Sciences.

Ebeling W. (2002). Urban Entomology. Entomology UC Riverside: University of California. Division of Agricultural

Ebrahimi E., Carpenter J.M. (2012). Distribution pattern of the hornets Vespa orientalis and V. crabro (Hymenoptera: Vespidae) in Iran. Zoology in the Middle East, 56, 63-66.

Gess S.K., Roosenchoon P.A. (2016). A preliminary survey of flower visiting by aculeate wasps and bees in the Dubai Desert Conservation Reserve, UAE. Journal of Hymenoptera Research. Pensoft Publishers \& International Society of Hymenopterists, 52, 81-141.

Ghahari H., Lehr P.A., Lavigne R.J., Hayat R., Ostovan H. (2007). New records of robber flies (Diptera, Asilidae) for the Iranian fauna with their prey records. Far Eastern entomologist, 179, 1-9.

Glaiim M.K. (2009). Hunting Behavior of the Oriental hornet, Vespa orientalis L., and defense Behavior of the honey bee, Apis mellifera L., in Iraq. Bull. Iraq nat. Hist. Mus., 10 (4), 17-30.

Goddard J. (2007). Physician's guide to arthropods of medical importance. Boca Raton: CRC Press.

Il'ina E.V., Gasanova N.M.-S. (2012). Vostochnyj shershen' Vespa orientalis Linnaeus, 1771 v Dagestane. Evraziatskij jentomologicheskij zhurnal, 11 (1), 544-545 (In Russian).

Kazenas V.L. (2014). Kollekcionnye materialy po obshhestvennym skladchatokrylym osam (Hymenoptera, Vespidae: Vespinae et Polystinae) Kazahstana v Institute zoologii MON RK (g. Almaty). Selevinija, 22, $193-196$ (In Russian).

Kazenas V.L., Nikolaev G.V. (2004). Chlenistonogie, opasnye dlja zhizni i zdorov'ja cheloveka. Uchebnoe posobie. Almaty: Kazak universitety (In Russian).

Kipjatkov V.E. (1991). Mir obshhestvennyh nasekomyh. L.: Izd-vo Leningradskogo universiteta (In Russian).

Klein Z., Zarabi L. (2003). Eradication of the oriental hornet with Fipronil-laced meat baits. Phytoparasitica, 31, 3 , 11-12.

Kudel' K.A. (1974). Semejstvo Nastojashhie, ili skladchatokrylye osy - Vespidae. In book: Vrediteli sel'skohozjajstvennyh kul'tur i lesnyh nasazhdenij. T. II. Vrednye chlenistonogie (prodolzhenie). Pozvonochnye, Kiev: Urozhaj (In Russian).

Kurzenko N.V. (1995). Semejstvo Vespidae - Skladchatokrylye osy. In book: Opredelitel' nasekomyh Dal'nego Vostoka.

T. IV. Setchatokryloobraznye. Skorpionnicy. Pereponchatokrylye. Ch. 1, SPb.: Nauka (In Russian).

Mejer N.F. (1936). Paraziticheskie pereponchatokrylye semejstva Ichneumonidae SSSR i sopredel'nyh stran. Opredeliteli po faune SSSR. 22. VI, M.-L.: Izd-vo AN SSSR (In Russian).

Meldebekov A.M., Kazenas V.L., Zhatkanbaeva Zh.M. i dr. (2011). Pervichnye materialy dlja sostavlenija Kadastra zhivotnogo mira Almatinskoj oblasti, Almaty, Nur-Print (In Russian).

Meldebekov A.M., Kazenas V.L., Bajzhanov M.H. i dr. (2011). Materialy k Kadastru zhivotnogo mira Almatinskoj oblasti. Chast' 1, Nasekomye, Almaty, Nur-Print (In Russian).

Mil'ko D.A. (1999). Zametki o skladchatokrylyh osah podsemejstva Vespinae Kyrgyzstana i sopredel'nyh territorij. Problemy ohrany i ustojchivogo ispol'zovanija bioraznoobrazija zhivotnogo mira Kazahstana. Materialy Mezhdunarodnoj nauchnoj konferencii 6-8 aprelja 1999 goda, Almaty, 136-137 (In Russian).

Mil'ko D.A. (2009). K voprosu o nezhelatel'nyh chuzhakah iz mira nasekomyh. Agro Vesti, 1 (1), 5 (In Russian).

Mokrousov M.V., Zrjanin V.A. (2015). Materialy po rannevesennej faune osoobraznyh Uzbekistana (Hymenoptera: Vespomorpha: Chrysidoidea, Scolioidea, Pompiloidea, Vespoidea, Apoidea [Spheciformes], Formicoidea). Jeversmannija. Jentomologicheskie issledovanija $v$ Rossii i sosednih regionah, 5. 29.V, 36-48 (In Russian).

Orlov B.N., Gelashvili D.B., Ibragimov A.K. (1990). Jadovitye zhivotnye i rastenija SSSR: Spravochnoe posobie dlja studentov vuzov po spec. «Biologija», M.: Vysshaja shkola (In Russian).

Pesenko Ju.A. (1981). Semejstvo Vespidae - Obshhestvennye skladchatokrylye osy. In book: Nasekomye i kleshhi vrediteli sel'skohozjajstvennyh kul'tur. T. IV. Pereponchatokrylye i dvukrylye, L.: Nauka (In Russian).

Plotkin M., Hod I., Zaban A., Boden S.A., et al. (2010). Solar energy harvesting in the epicuticle of the oriental hornet (Vespa orientalis). Naturwissenschaften, 97, 12, 1067-1076.

Popov V.V. (1948). Otrjad Hymenoptera. Pereponchatokrylye. In book: Zhivotnyj mir SSSR. T. II. Zona pustyn', M.-L.: Izdvo AN SSSR (In Russian).

Popov V.V. (1949). Otrjad Hymenoptera. Pereponchatokrylye. In book: Vrednye zhivotnye Srednej Azii: Spravochnik, L.: Izd. AN SSSR (In Russian).

Potter M.F., Beavers G.M. (2005). Public Health Pest Management. A training Guide. University of Kentucky.

Robinson W.H. (2005). Handbook of Urban Insects and Arachnids. Cambridge: Cambridge University Press.

Romashkova O.P., Dashev G.C. (2005). Bumazhnye osy - ob\#ekt medicinskoj dezinfekcii. Materialy XII Vserossijskogo mirmekologicheskogo soveshhanija «Murav'i i zashhita lesa» i satellitnogo soveshhanija "Jekologija i povedenie obshhestvennyh pereponchatokrylyh: teoreticheskie problemy i prakticheskoe ispol'zovanie», Novosibirsk, 252-256 (In Russian).

Roques A., Kenis M., Lees D., Lopez-Vaamonde C., et al. (2010). Alien terrestrial arthropods of Europe. BioRisk, 4 (1) (Special Issue), 570. 
Temreshev, I.I. On the expansion of the areas of Vespa orientalis and.... Acta Biologica Sibirica, 2018, 4(1), 38-45

Spradbery J.P. (1973). Wasps. An account of the biology and natural history of solitary and social wasp. University of Washington Press.

Temreshev I.I. (2017). Vrediteli zapasov i syr'ja, rasprostranennye na territorii Respubliki Kazahstan, i nekotorye soputstvujushhie i karantinnye vidy (vidovoj sostav i kratkaja tehnologija zashhitnyh meroprijatij). Izdanie vtoroe, dopolnennoe i pererabotannoe, Almaty: Nur-Print (In Russian).

Temreshev I.I., Kazenas V.L., Chil'debaev M.K., Isenova G.Zh., Kozhabaeva G.E. (2015). Predvaritel'nyj spisok indikatornyh vidov nasekomyh Juzhnogo Kazahstana, Almaty: Nur-Print (In Russian).

Tobias V.I. (1978). Semejstvo Vespidae. In book: Opredelitel' nasekomyh evropejskoj chasti SSSR. T. III. Ch. 1. Pereponchatokrylye, L.: Nauka (In Russian).

\section{Citation:}

Temreshev, I.I. (2018). On the expansion of the areas of Vespa orientalis and Polistes wattii (Hymenoptera: Vespidae) on the territory of the Republic of Kazakhstan. Acta Biologica Sibirica, 4 (1), 38-45.

Submitted: 12.12 .2017 . Accepted: 20.02 .2018

crossref http://dx.doi.org/10.14258/abs.v4i1.3915

(C) 2018 by the authors. Submitted for possible open access publication under the terms and conditions of the Creative Commons Attribution (CC BY) license (http://creativecommons.org/licenses/by/4.0/). 